\title{
WHEAT LANDRACES PRODUCTION ON FARM LEVEL IN TURKEY; WHO IS GROWING IN WHERE?
}

\author{
Mustafa Kan'1, Murat Kucukcongar ${ }^{1}$, Alex Mourgounov², Mesut Keser ${ }^{3}$, Fatih Ozdemir'1, \\ Hafiz Muminjanov ${ }^{4}$ and Cal Qualset ${ }^{5}$
}

\author{
${ }^{1}$ Bahri Dagdas International Agricultural Research Institute (BDIARI), Konya, Turkey; ${ }^{2}$ International Maize and \\ Wheat Improvement Center (CIMMYT), Turkey; ${ }^{3}$ International Center for Agricultural Research in Dry Areas \\ (ICARDA), Turkey; ${ }^{4}$ FAO Sub-regional Office for Central Asia (FAO-SEC), Turkey; ${ }^{5}$ University of California, \\ Davis, California USA. \\ "Corresponding author's e-mail: mustafakan@gmail.com
}

\begin{abstract}
Turkey is one of the centers of origin for wheat which grows on 8.5 million ha and annually produces 20-24 million tons. Though modern varieties have been widely grown in most areas, some Wheat Land Races (WLR) are being planted in some niche locations, especially in remote and mountainous areas mainly for home consumption with limited marketing. It is a reality that WLR are no longer preferred by most producers because of the higher yield potential of modern wheat varieties. In fact, cultivation areas and production of WLR decreased dramatically which might lead to the loss of or even extinction of WLR. In this study, Ministry of Food Agriculture and Livestock (MFAL) researchers with ICARDA and CIMMYT scientists created a project to determine the current status of WLR compared to the national level in 2009. With contribution from FAO in 2012 and 2013, the project was finalized in 2014 and in total, 1873 questionnaire forms were completed with 1661 WLR producers via face to face interviews in 65 provinces of Turkey. Research areas were determined by using the "Purposive Sampling Method" by means of pre-interviews with different institutions. The results show that not only are agronomic characters affecting production process decision making but so are other factors like socio-economic, geographical and farm characteristics which are also affecting the household decision on maintaining the WLR production in Turkey. The farmers who are growing only WLR are allocating $40.43 \%$ of their land to the WLR and $16.73 \%$ of farmers are growing both WLR and modern wheat varieties (MWV). Farmers are producing WLR in general highland areas (more than 1,200 m) and the market places for these farmers is further than the other farmer's settlements.
\end{abstract}

Keywords: Wheat landraces, on-farm conservation, socio-economic characteristics, crop domestication

\section{INTRODUCTION}

Turkey is the center of origin and domestication for many crop species (Davis, 1985; World Bank, 1993; Kaya et al., 1997; Tan, 1998). Diverse geological and climatic conditions of Turkey have given rise to unique plant species represented nowhere else in the world. Over $30 \%$ of 8,800 species found in the country are endemic to Turkey (World Bank, 1999). The country is the center of origin and a source of genetic diversity for globally important plants which were first domesticated from wild species and still exist in Turkey. In fact, Turkey's importance in relation to progenitor species, such as wheat, barley, oats, lentil chickpea, apple and pear, used in Mediterranean and temperate agricultural systems is virtually unprecedented (Harlan, 1995; Bennett et al., 1998). WLR are one of the most important genetic resources for Turkey. The archeological findings have shown that Eastern Mediterranean regions surrounding the rivers Tigris and Euphrates were the first places, where wheat was processed. Wheat is one of the oldest plants that has been cultivated by mankind. Archeological excavations showed that ancient people living around Şanliurfa (Karacadag Mountains), a province in the Southeastern part of Turkey, planted Einkorn wheat (Triticum boeoticum) approximately 10.000-12.000 years ago, which is the wild form of today's commercial wheat. Today [Einkorn wheat] is still used for animal feed in some areas (Nesbitt and Samuel, 1996; Zencirci and Birsin, 2004; Tanno and Willcox, 2006; Yavuz, 2010).

The contribution of landraces to breeding and genetic research is very important. They are also a cultural heritage and an indication for the wealth for a country. In many studies, landraces were evaluated in terms of social and private values. The social value of landraces has been described by examples of the economic contribution of exotic crops and crop varieties (e.g. Iltis, 1982) and analytically by the contribution of germplasm to breeding programs (Evenson and Gollin, 1994; National Research Council 1993). The private value of landraces is suggested by their persistence in farming systems where alternative varieties exist (Brush 1995) and by studies on the evaluation and selection of local varieties (Bellon, 1996; Zimmerer 1996; Sperling et al., 1993). As the results of these studies, 
landraces should be considered an important natural resource and they must be conserved and used for future generations.

Like other countries, extinction of genetic resources and genetic erosion are some of the main problems facing Turkey. Modern agriculture, conventional breeding and the liberal use of high inputs have resulted in the loss of genetic diversity and the stagnation of yields in cereals in less favorable areas. Increasingly, landraces are being replaced by modern cultivars which are less resilient to pests, diseases and abiotic stresses and thereby lost is a valuable source of germplasm for meeting the future needs of sustainable agriculture in the context of climate change. Where landraces persist there is concern that their potential is not fully realized (Newton et al., 2010). However, landraces are still widely grown in developing countries, particularly in harsh environments (Khan et al., 2012). Today Turkey has achieved selfsufficiency in many products such as wheat and it is also one of the largest wheat exporting countries. New and improved varieties and production techniques have been the biggest reasons for reasons for Turkey's success in wheat exportation. Interestingly, the amount of production area of wheat in Turkey has decreased about 1.5 million ha from 1990 to 2014, but the total production of wheat has remained stable. This means that the new wheat varieties in that period contribute more than $10 \%$ via their yield potential (TSI, 2015). Increasing wheat production depending on high yield potential can be seen as a positive development however accessing the new wheat varieties for production process has led to the extinction of genetic resource (local wheat varieties/landraces). A notable past study in Turkey showed that the share of modern wheat varieties in Turkish agriculture was very high and the share of local landraces was under the $1 \%$ percent in total wheat production area in the country (Mazid et al., 2009). This result was evidence that there was a decline in crop genetic diversity in wheat crop.

The evaluation of landraces is important to define and all efforts must be made to conserve them. If we understand why farmers are producing wheat landraces and subsequently know the problems of these farmers we can improve new policy strategy to conserve genetic resources in situ conservation on their land. To date, there have been studies on landrace potential in Turkey (Bardsley and Thomas, 2005; Kurizch, 2006; Kurizch and Meng, 2006; Meng, 1997, Gauchan et al., 2005; Smale et al., 2003; Nagarajan et al., 2007; Benin et al., 2004, Brush and Meng, 1998). While some scientist collect landraces and research their agronomical features to determine usage opportunities in breeding, there are few studies on characteristics of farmers who grow them and in-situ conservation of landraces. In almost every study done in Turkey, scientist mentioned that landraces are important potential for breeding and they should be used for breeding. The importance of landraces has been emphasized by many scientists in Turkey however genetic erosion has not been prevented and it continues to this day.
The purpose of the present study was to identify the farmers who are still growing WLR and analyze their socio economic characteristics. This information will be helpful for the public and policy makers to support on-farm conservation of WLR in Turkey.

\section{MATERIALS AND METHODS}

Data sources: The data was collected at a household level that focused on socio-economic status by using questionnaire forms from 1873 households in the study area. The survey was conducted in 523 villages located within 172 districts selected from 65 Turkish provinces between 2009-2014 years. Provinces and districts were selected based on the extent of the Mirza Gokgol study (1939). Provincial Directorates of Food, Agriculture and Livestock, research institutes and universities were all utilized to select the survey areas in the chosen provinces (Districts and villages) by using "Purposive Sampling Method" (Ral, 1968). Interviews were conducted by agricultural experts working in different institutes, universities, NGOs, and government agencies with the aim of clearly defining the areas where we would visit for the study. The study area is shown in Figure 1.

The socioeconomic survey covered a broad range of information regarding household characteristics, production data (yield, seed amount, fertilizer amount and other production and harvesting techniques), and landrace features (height, seed color, preferred and non-preferred characters of landraces, usage aims, wheat type). Households participating in the surveys ranged from those which cultivated only WLR to those which cultivated both modern varieties and WLR. Survey forms were completed during face to face interviews with the farmers. The participating farmers were chosen in cooperation with the pertinent village administrators.

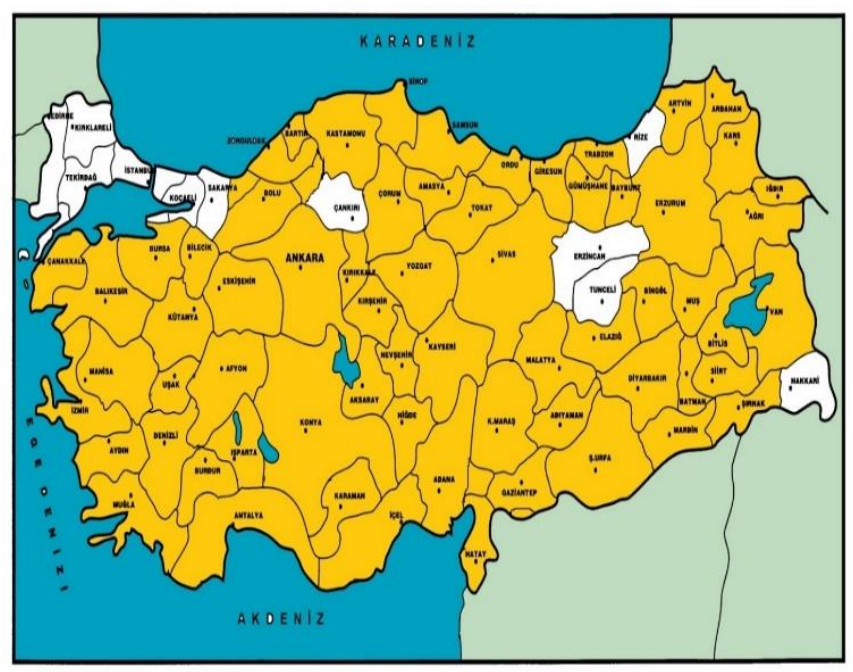

Figure 1. Wheat landrace survey areas by provinces in Turkey. 
Data analyses: In this study, the farmers were classified into two groups according to their preferred wheat variety use.

- If the farmers produced only wheat landraces in their production system, it was coded as "Only Wheat landraces".

- If the farmers produced both wheat landraces and commercial wheat varieties together in their production system, it was coded as "Both Wheat landraces and Commercial Wheat Varieties".

All analyses for the project were done according to the preferred wheat variety used by the farmers. Stata- 13 statistical software was used to analyze the data gathered from the study area. First, a descriptive analysis was used to describe the basic features of the data in the study. This analysis provides simple summaries of the characteristics of the samples such as measures of dispersion and central tendency. However, there is a limitation with this analytical procedure which is that the descriptive statistics do not show the relationship among the variables and the influence that each variable may have on the response. The descriptive analysis does however often provide guidance for more advanced quantitative analyses.

In this study, categorical variables were showed with cross tabulations which are useful for summarizing categorical variables. The chi square test is used to measure whether there is some level of association among categorical variables in two-way and multi-way contingency tables. Variables for which the test statistic is significant at a set cut-off point are considered associated, while those for which the test statistic is not significant are not associated. However, the test does not indicate the direction, or even the magnitude of the association, thus, it is not sufficient to use this analytical approach alone.

Pearson's chi-squared was used to assess two types of comparison tests of independence. A test of independence evaluates whether paired observations on two variables, expressed in a contingency table, are independent of each other. The value of the test-statistic is; (Kesici and Kocabas, 2007).

$$
\chi^{2}=\sum_{i=1}^{n} \frac{\left(O_{i}-E_{i}\right)^{2}}{E_{i}}
$$

Where, $\chi^{2}=$ Pearson's cumulative test statistic, which asymptotically approaches a $\chi^{2}$ distribution, $\mathrm{O}_{\mathrm{i}}=$ an observed frequency; $E_{\mathrm{i}}=$ an expected (theoretical) frequency, asserted by the null hypothesis; $\mathrm{n}=$ the number of cells in the table.

The maximum $20 \%$ of total cells' frequency values should be less than 5 in created cross-tables to accept the Chi Square analysis results as reliable and no cell frequency should fall below 1. If this limit is exceeded, reliability of the results obtained from the chi-square analysis will be questioned (Bayazit and Oguz, 1998). When the Chi-Square analysis is deemed unreliable, the "Likelihood Ratio" value is used. In this paper the data actualize the condition of the criteria of Chi
Square analysis. Because of that "Likelihood Ratio" value was not used. Data was tested in 90\%, 95\% and $99 \%$ confidence intervals.

The T-test was used to compare the means from two independent variables. This test was used to compare two small sets of quantitative data when samples were collected independently of one another. The criterion of this test is that the samples must be collected from two different populations or from randomly selected individuals from the same population at different times. "Levene's Test" was used to compare the variances equality of 2 groups. If the result of Levene's Test was $p<0,05$, the variances were not equal in each group and in this case the T-test was used in the absence of equal variance (Buyukozturk, 2010; Ergun, 1995).

The socio-economic index (SEGE-2004) was used when wheat landraces were grown. This index was improved by the Ministry of Development (MoD) in 2004, when an index was produced that united all the socio-economic characteristics of a district (the next smaller administrative unit of a province) in Turkey. Within the scope of SEGE-2004, the development levels of districts were measured through variables chosen from different categories. In total, 58 variables in $10 \mathrm{sub}$ categories were used by MoD (MoD, 2004).

One of the factors taken into account was the presence of family labor because, agriculture is a labor-intensive activity. The presence of labor is an important variable in the sustainability of the farms in the study area where subsistence farming systems is common. To calculate the farms' labor force in their household, conversions of the people in the household to "Man Labor Unit (MLU)" was done. Of course, not all workers have the same capacity for work. Although children can do useful work, they cannot yet do the heavy work of an adult. Women, in addition to working in the fields do other tasks such as fetch water and cook meals and therefore typically do not work in the field as long as the men. It is therefore difficult to make a direct comparison of the work that can be done by different households. The coefficients presented in Table 1 were considered in this conversion.

Table 1. The coefficients for man labor unit conversions.

\begin{tabular}{lc}
\hline Demographic groups & $\boldsymbol{\alpha}$ coefficient \\
\hline Children $(6$ age $<)$ & 0.00 \\
Children $(7-14$ age $)$ & 0.50 \\
Men $(15-49$ age $)$ & 1.00 \\
Women $(15-49$ age $)$ & 0.75 \\
Men $(50$ age + ) & 0.75 \\
Women $(50$ age + ) & 0.50 \\
\hline
\end{tabular}

Source: Erkuş (1979)

Farmer's decisions on landrace cultivation (only wheat landrace cultivation or both wheat landrace and improved wheat varieties cultivation) were analyzed. To analyze the influence of each explanatory variable on the dependent 
variable, which is a dichotomous variable, the binary logistic regression was used as a method (Maddala, 1983; Grene, 2000). Two different binary logistic regressions were applied for dependent variables, such as only wheat landraces cultivated $(\mathrm{y}=1)$, or both wheat landraces and improved wheat varieties cultivated $(\mathrm{y}=2)$. Dependent variables were assumed as socio-economic and geographical location facts, because we thought that currently change of any of these factors will impact farmers' decisions. The logit model is (Agresti, 1996):

$$
\operatorname{Pr} o b(y=1)=\frac{e^{x \beta}}{1+e^{x \beta}}
$$

Where, Prob $(y=1)$ is the probability $p$, e is the base of natural logarithm, $\mathrm{x} \beta$ is the standard logistic distribution function and $\mathrm{x}$ is the explanatory variable vector, which includes the selected factors.

\section{RESULTS AND DISCUSSION}

Socio-economic factors: Different socio-economic characteristics of the farm are important determiners of maintenance of WLR affecting the farmers' behaviors and attitudes. In this context, age, education levels of household heads, the distribution of existing labor forces according to the sex and usage households were analyzed. Socio-economic characteristics of the farm households were also examined including demographic characteristics, land assets and land use. The demographic structure of the farm households is also a variable affecting willingness of the farmers' to produce WLR or MWL.

The socio economic characteristics of the village are as important variables as socio economic characteristics of the farm households. The characteristics of the village can give information on the access to technology, inputs, markets and social facilities. Socio-economic development index which was created by the Ministry of Development in 2003 (Dincer et al., 2003) was used in the analysis. This index included social and economic parameters and accordingly the counties were divided into 6 development groups with 1 being less developed and 6 - most developed. Out of 189 districts in the study area $3.7 \%$ fell into groups 1 and 2; 38.10\% were in group $3 ; 28.57,14.81$ and $14.81 \%$ in groups 4,5 and 6, respectively (Fig. 2). This shows that the areas where WLR are grown belong to middle and less developed counties.

Socio-economic situations of villages also affect the preference of farmers. In the study, it was found that the farmers producing only WLR in their farms live in counties with a lower socio-economic development index when compared with the farmers producing WLR and MWV together (Fig. 3).

The first demographic factor is household size. Previous research has demonstrated a positive relationship between farm size and the adoption of modern varieties (Perrin and Winkelmann, 1976; Feder et al., 1985). Larger farms may benefit from the economics of scale, be able to dedicate some proportion of land to experimenting with modern varieties, or face lower information costs relative to small farmers (Kruzich and Meng, 2006). The average Turkey household size is 3.7 people according to the Turkey Statistical Institute (TSI) census in 2012 (TSI, 2013). The distribution of household size in the study regions was higher than the country average, but there is statistically no difference between two groups (WLR and WLR \& MWV) (Table 2).

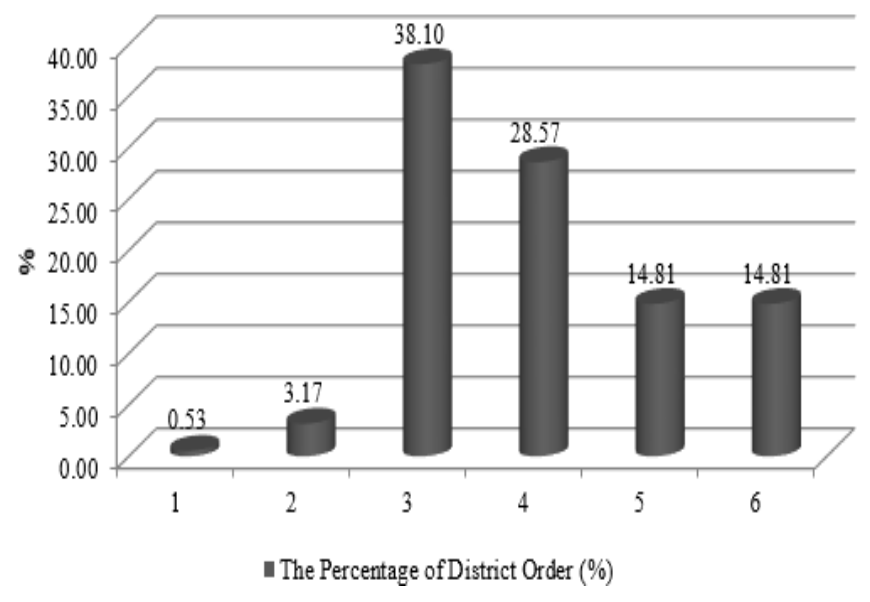

Figure 2. The distribution of districts order according to the socio-economic development index.

Table 2. The labor availability of the farms producing wheat landraces.

\begin{tabular}{lcccc}
\hline Variables & Only Landrace & $\begin{array}{c}\text { Both Landrace } \\
\text { and Commercial }\end{array}$ & Average & T Value \\
\hline Total Number of Male in $\mathrm{HH}^{1}$ & 2.87 & 2.91 & 2.88 & -0.38 \\
Total Number of Female in HH & 2.59 & 2.66 & 2.61 & -0.78 \\
Number of People in HH & 5.46 & 5.57 & 5.48 & -0.65 \\
Male MLU & 2.18 & 2.24 & 2.20 & -0.73 \\
Female MLU & 1.51 & 1.60 & 1.53 & -1.71 \\
Total MLU & 3.69 & 3.84 & 3.73 & -1.29 \\
Total MLU/Number of People in HH & 0.68 & 0.69 & 0.68 & -1.69 \\
\hline
\end{tabular}

${ }^{1} \mathrm{HH}$ : Household ${ }^{2}$ : MLU: Man Labor Unit 


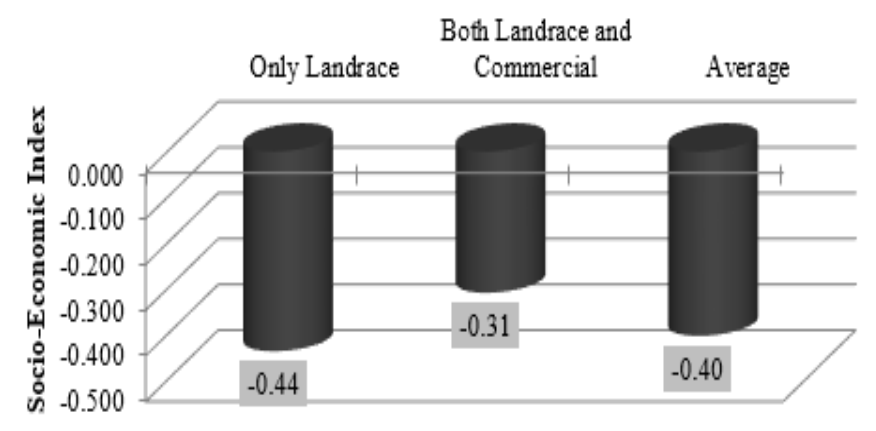

- Socio-Economic Index of District

Figure 3. Socio-economic development index values of districts according to wheat landrace production features.

Household size alone is not the most important aspect. What matters in distribution of the population according to the sex and age and labor force of the farm household. The presence of labor is important for the continuity of the agricultural sector, which is a labor-intensive sector. In this study, the labor force of the farm household was calculated as Man Labor Unit (MLU) and considered the age and sex of the population. According to Table 2, there were no significant differences in terms of household size and Man Labor Unit between the farmers who are growing only WLR and the farmers who are growing both WLR and MWV together.

Another factor examined in this study was the age of household heads. When farms growing wheat landraces have a more patriarchal family structure, household heads play an important role in the decision-making processes. Some of the variables affecting the household heads decision-making process are age and education. Age brings experience, however, it is widely accepted that older people often behave more conservatively and are thus less open to new ideas. In this situation, older farmers could grow more wheat landraces in their production system. The inhabitants of Turkish villages are typically industrious and willing to produce crops which are suitable for the agro-climatic conditions of the region in order to meet family needs and offer surplus production at the local market. Because of this the great diversity in the landraces for many crops is maintained. The fact that these varieties, with excellent taste qualities and were created many decades ago in the respective micro-areas with characteristic agro-climatic peculiarities, are grown by older farmers makes this study activity in collection and preservation of this wealth priceless. The desire to cultivate landrace diversity is not being passed on to younger generations as the study showed that the age of farmers growing wheat landrace to be above 50 years of age. The average age of household heads in the research area was 53 years and the value varied according to the groups but in both groups the age was above the 50 years of age. This shows that the farmers engaged in wheat landrace production constitute older members of the rural population. Except age factors, none of socio economic factors like the number of people and the potential of labor force in the households, sex of people affect farmers' behaviors on preference between only WLR or both MWV and WLR being grown. The age of household heads was found as an important factor at a 90\% confidence level (Chi square: 2.95, p:0.08). In the study area, the farmers above the age of 50 mostly preferred to produce only wheat landraces when compared to farmers less than 50 years of age (Fig.4.).

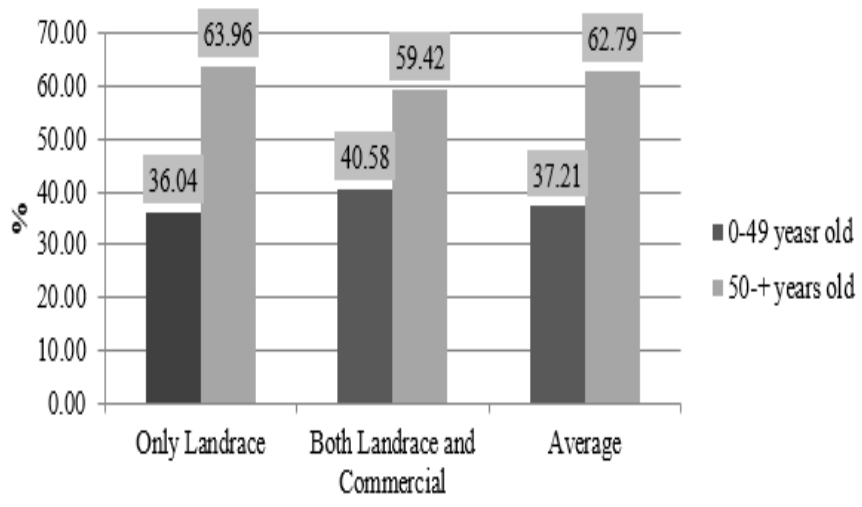

Figure 4. The preferences of the farmers on wheat landrace production system according to their age.

Another demographic factor examined in the study was the educational level of household heads. It is known that the literacy rate is generally high in place where the agricultural activities are being done consciously (Şahin and Yilmaz, 2008). Educational status is also one of the most important factors in determining people's behavior and decisions (Kan, 2012). The increase in the level of education affects two different domains. First, as the level of education increases, people will likely engage in more commercialized market oriented activities and as result the production system will use modern technology and materials and allocate more land for modern wheat. Second, as the level of education increases, people may want to engage in more organic, local, subsistence or recreational agricultural activities. In this system, despite the low yield, local varieties are preferred in the production system due to grain quality (flavor and aroma). The effect of educational levels on willingness to produce WLR is shown in Table 3. As the educational level of household heads increased the number of farms growing more wheat landraces in their production system increased as well.

The farms' land assets and the share of wheat landrace area in total cultivated area were presented in Table 4. Previous research has demonstrated a positive relationship between farm size and the adoption of modern varieties (Perrin and Winkelmann, 1976; Feder et al., 1985). Larger farms may benefit from the economics of scale, be able to dedicate some 
Table 3. The change on production features of the farmers according to their education level.

\begin{tabular}{lccc}
\hline Education Level & Only Landrace (\%) & Both Landrace and Commercial (\%) & Total (\%) \\
\hline Illiterate & 6.46 & 8.00 & 6.85 \\
Literate & 16.60 & 10.89 & 15.13 \\
Primary School & 69.72 & 71.33 & 70.13 \\
Secondary School & 5.61 & 9.33 & 6.57 \\
University & 1.61 & 0.44 & 1.31 \\
Total & 100.00 & 100.00 & 100.00 \\
\hline
\end{tabular}

$\chi^{2} 19.04 \quad$ S.D.:4 p value:0.00 $4: 0.10$

Statistically significant at $99 \%$ confidence level

Table 4. The change on production features of the farmers according to their farm size.

\begin{tabular}{lccc}
\hline Production feature & Total cultivated land (Ha) & Total wheat land (Ha) & $\begin{array}{c}\text { Total wheat landrace } \\
\text { land (Ha) }\end{array}$ \\
\hline Only Landrace & 6.01 & 2.48 & 2.43 \\
Both Landrace and Commercial & 10.40 & 5.49 & 1.74 \\
Total & 7.16 & 3.27 & 2.25 \\
T Value & $-5.65^{* * *}$ & $-7.45^{* * *}$ & $-4.00^{* * *}$ \\
\hline
\end{tabular}

* Significant at $90 \%$ confidence interval; $* *$ Significant at $95 \%$ confidence interval; *** Significant at $99 \%$ confidence interval

Table 5. Number of farms by type of landrace production with respect to elevation.

\begin{tabular}{|c|c|c|c|c|c|c|}
\hline \multirow[t]{3}{*}{ Type of landrace production } & \multicolumn{4}{|c|}{$\begin{array}{l}\text { Elevation } \\
\end{array}$} & \multirow{2}{*}{\multicolumn{2}{|c|}{ Total }} \\
\hline & \multicolumn{2}{|c|}{ Lowland $(<1,200 \mathrm{~m})$} & \multicolumn{2}{|c|}{ Highland $(\geq 1,200 \mathrm{~m})$} & & \\
\hline & Count & $\%$ & Count & $\%$ & Count & $\%$ \\
\hline Only landraces & 639 & 66.15 & 615 & 88.24 & 1,254 & 75.41 \\
\hline Both landraces and modern varieties & 327 & 33.85 & 82 & 11.76 & 409 & 24.59 \\
\hline Total & 966 & 100.0 & 697 & 100.0 & 1,663 & 100.00 \\
\hline
\end{tabular}

$\chi^{2}: 106.49 \quad$ S.D.:1 p value:0.00 $\quad \varphi:-0.25$

Statistically significant at the $99 \%$ confidence level

proportion of land to experimenting with modern varieties, or face lower information costs relative to small farmers (Kruzich and Meng, 2006). In this study the average farm size was 7.16 ha and $86.68 \%$ of it consisted of dry area (rain fed production system). It was determined that $45.69 \%$ of the total cultivated area from the farmers surveyed was allocated to wheat production and $68.84 \%$ of this wheat area was allocated to wheat landrace production. The larger the farm size the more MWV's are produced in larger share. If the farmer has a large area, they often think about producing more marketable products and they don't allocate more area for WLR production.

Geographical factors: Since geographical structure affects both quality and yield in the production process, it is an effective factor in farmers' decisions as to what products they will produce and to what extent to which they will produce them. There are many elements that make up the geographical structure. One of them is elevation, which is an effective factor determining the maintenance of wheat landrace production. It also has a positive impact on diversity at the farm level (Kruzich, 2006). In this study, we determined that the majority of wheat landrace production took place at higher elevations as presented in Table 5.

Another important variable impacting the decision of farmers to grow wheat landraces was the distance to the market from the production site. The likelihood of subsistence-level agricultural production is high in remote areas that are far from the markets. The average distance to market of the farmers producing wheat landraces is presented by provinces in Table 6. In the study, $23.69 \%$ of all farms had a distance to market greater than $25 \mathrm{~km}$. As the distance to the market increases, the proportion of farmers growing wheat landraces only increased (Table 6). Similar studies showed that market characteristics affect biodiversity outcomes. Van Dusen (2000) measured market integration with respect to distance to a regional market, use of hired labor, and international migration, and he found that the characters negatively affected diversity outcomes. Brush et al. (1992) studied the diversity of potato CGR in Peru and compared two valleys with different levels of market integration. They found that increased level of market integration decreased the overall level of diversity, since commercial production increased the area under simplified production systems with improved 
Table 6. Number of farms by type of landrace production with respect to distance to market.

\begin{tabular}{lcccccc} 
Type of landrace production & \multicolumn{3}{c}{ Distance to market } & \multicolumn{3}{c}{ Total } \\
\cline { 2 - 6 } & \multicolumn{2}{c}{$<\mathbf{2 5} \mathbf{~ k m}$} & \multicolumn{2}{c}{$\geq \mathbf{2 5} \mathbf{~ k m}$} & & Count \\
\cline { 2 - 7 } & Count & \% & Count & \% & \% \\
\hline Only landraces & 981 & 74.89 & 329 & 25.11 & 1,310 & 100.00 \\
Both landraces and modern varieties & 375 & 80.39 & 92 & 19.70 & 467 & 100.00 \\
Total & 1,356 & 76.31 & 421 & 23.69 & 1,777 & 100.00 \\
\hline
\end{tabular}

$\chi^{2}: 5.58 \quad$ S.D.: $1 \quad$ p value: $0.02 \quad \varphi:-0.06$

Statistically significant at the $90 \%$ confidence level

Table 7. Summary statistics on the factors including the empiric model.

\begin{tabular}{|c|c|c|c|c|}
\hline \multirow[t]{2}{*}{ Variables } & \multirow[t]{2}{*}{ Variable description } & \multicolumn{2}{|c|}{ Summary statistics } & \multirow{2}{*}{$\begin{array}{c}\text { All samples } \\
(\mathrm{N}=1,721)\end{array}$} \\
\hline & & $\begin{array}{l}\text { Wheat landraces } \\
\text { only }(n=1,258)\end{array}$ & $\begin{array}{c}\text { Both landraces and } \\
\text { modern varieties }(n=463)\end{array}$ & \\
\hline \multicolumn{5}{|c|}{ Household head characteristics } \\
\hline TRY & $\begin{array}{l}\text { Has the household head tried } \\
\text { improved varieties on his farm? } 1 \text { : } \\
\text { yes; } 2 \text { : no }\end{array}$ & $1.85( \pm 0.37)$ & $1.04( \pm 0.20)$ & $1.63( \pm 0.49)$ \\
\hline AGE (Dummy) & $\begin{array}{l}1:<45 \text { years old } \\
2: \geq 45 \text { years old }\end{array}$ & $1.84( \pm 0.37)$ & $1.81( \pm 0.39)$ & $1.83( \pm 0.38)$ \\
\hline EDUC (Dummy) & $\begin{array}{l}\text { 1: Illiterate } \\
\text { 2: Literate } \\
\text { 3: Primary School } \\
\text { 4: Secondary School } \\
\text { 5: University }\end{array}$ & $2.83( \pm 0.69)$ & $2.84( \pm 0.72)$ & $2.84( \pm 0.70)$ \\
\hline \multicolumn{5}{|c|}{ Farm characteristics } \\
\hline LSHARE & $\begin{array}{l}\text { Percentage of wheat landrace area } \\
\text { in total area }(\%)\end{array}$ & $48.49( \pm 31.12)$ & $22.15( \pm 18.62)$ & $41.41( \pm 30.62)$ \\
\hline $\mathrm{HHH}$ & $\begin{array}{l}\text { The amount of land (ha) per } \\
\text { household member }\end{array}$ & $1.34( \pm 2.24)$ & $2.22( \pm 3.01)$ & $1.57( \pm 2.49)$ \\
\hline \multicolumn{5}{|c|}{ Geographical characteristics } \\
\hline MDIST (Dummy) & $\begin{array}{l}1: 0 \text { to } 40 \mathrm{~km} \\
2: \geq 40 \mathrm{~km}\end{array}$ & $1.73( \pm 0.45)$ & $1.67( \pm 0.47)$ & $1.71( \pm 0.45)$ \\
\hline ELEVATION & $\begin{array}{l}\text { The elevation of farms growing } \\
\text { wheat landraces }(\mathrm{m})\end{array}$ & $\begin{array}{l}1,213.54 \\
( \pm 414.22) \\
\end{array}$ & $969.40( \pm 312.31)$ & $\begin{array}{l}1,148.68 \\
( \pm 404.32) \\
\end{array}$ \\
\hline
\end{tabular}

Note: Figures in parentheses represent standard deviations.

varieties. Meng's (1997) study of the diversity of wheat varieties in Turkey integrated several possible explanations into a comprehensive model. Market variables were important explanatory factors in the probability of planting landraces.

Econometric model: The definitions, descriptions, and summary statistics of independent variables included in the binary logistic regression analysis were given in Table 7 . The independent variables considered in this analysis can be broadly classified as: household head characteristics, farm characteristics, and geographical characteristics. In similar studies carried out in Turkey by Kruzich and Meng (2006), they classified these factors, which affect farmers' variety choices, into six classes: socioeconomic characteristics, plotlevel characteristics, market access, variety characteristics, province, and agro-eco zone. Negassa et al. (2012) classified their independent variables as: household head characteristics, farm characteristics, market access and institutions, agro-ecotypes, and provincial dummy variables in their household decision model.

The results of binomial logit regression coefficients are presented in Table 8 . The household characteristics such as education, and experience of household on growing improved wheat varieties appear to have significant effects on the household's choice of wheat varieties (wheat landraces only or both wheat landraces and improved varieties). Similarly, the effects of farm and geographical characteristics were statistically significant. As a result of binary logistic regression, the farmers' experience in production of modern wheat varieties affects their choice of wheat varieties to grow. Farmers who have grown modern wheat varieties before tended not to continue with modern wheat variety production. They usually continue to produce both modern wheat 
Kan, Kucukcongar, Mourgounov, Keser, Ozdemir, Muminjanov \& Qualset

Table 8. Estimation of binomial logistic regression coefficients for wheat variety choice model.

\begin{tabular}{|c|c|c|c|c|c|c|}
\hline Explanatory variables & B & S.E. & Wald & df & Sig. & $\operatorname{Exp}(B)$ \\
\hline TRY & $-5.109 * * *$ & 0.282 & 328.695 & 1 & 0.000 & 0.006 \\
\hline MDIST & $-0.538^{*}$ & 0.308 & 3.048 & 1 & 0.081 & 1.739 \\
\hline LSHARE & $-0.037 * * *$ & 0.004 & 74.990 & 1 & 0.000 & 0.964 \\
\hline AGE & 0.388 & 0.377 & 1.059 & 1 & 0.303 & 1.475 \\
\hline EDUC & $-0.301 * *$ & 0.151 & 4.001 & 1 & 0.045 & 0.740 \\
\hline ELEVATION & $-0.002 * * *$ & 0.000 & 63.129 & 1 & 0.000 & 0.998 \\
\hline $\mathrm{HHH}$ & $0.007^{*}$ & 0.004 & 3.368 & 1 & 0.066 & 1.007 \\
\hline Constant & $10.803 * * *$ & 0.986 & 119.971 & 1 & 0.000 & $49,152.323$ \\
\hline Number of observation & 1,625 & & & & & \\
\hline Log-Likelihood value & 680.52 & & & & & \\
\hline Cox \& Snell R square & 0.52 & & & & & \\
\hline Nagelkerke R square & 0.76 & & & & & \\
\hline \multicolumn{7}{|l|}{ Percent correctly predicted } \\
\hline LR only & 93.77 & & & & & \\
\hline Both MV and LR & 88.15 & & & & & \\
\hline Overall correct prediction & 92.31 & & & & & \\
\hline Hosmer and Lemeshow test & 16.40 & & & & & \\
\hline
\end{tabular}

varieties and wheat landraces. As it is known, modern wheat varieties have better yield potential and greater value in markets than wheat landraces. The probability of this variable is also high (Table 8).

The other household head characteristic was the age of household head. Indigenous knowledge (IK), including knowledge of crop diversity, is often held by the older members of a community. This link can be a precarious one, as knowledge can be lost if elders do not pass IK down to younger generations (Jarvis et al., 2000). In the model, the variety was represented by a dummy variable as equal to older than 45 years versus younger than 45 . The result was that age was not found significant (Table 8). Negassa et al. (2012) found the age as insignificant on the household's choice of wheat varieties in Turkey.

Education was the other factor we examined in the model on affecting farmers' decisions. The more educated farmers preferred to produce only wheat landraces in their farming system (Table 8). We think that there are two main reasons of this result. One of them is that people want to use the advantage of wheat landrace marketing as local products, especially Siyez wheat in Kastamonu province. The second is that the more educated people prefer to produce this landraces for their consumption for healthy life (hobby farming). Kruzich and Meng (2006) and Meng (1997) stated that a household decision maker with more years of farming experience was more likely to cultivate traditional varieties, while more education resulted in a significantly lower probability of landrace cultivation. Negassa et al. (2012) found that household characteristics such as education, age, and farming experiences of household heads appear to have no significant effect on the household's choice of wheat varieties. Similarly, the effects of farm household characteristics like dependency ratio and number of car ownership on farm household's wheat variety choice was not statistically significant. However, variables which appeared to significantly influence farm household's wheat variety choice were: household size, number of cattle owned, number of buildings on farm, farm size, farm fragmentation, percentage of irrigable farm plots, and the regional dummy variables.

As a result of the research, the average farm size was 7.16 ha over the whole sample and farm size showed great variability across wheat variety choices. For example, the average farm size for the wheat-landraces-only choice was about 6.01 ha, which is about double that for the choice of both landraces and modern wheat varieties (10.40 ha) (Table 4). Thus, households growing wheat landraces only tend to have small farm size as compared to those growing modern wheat varieties only and those households simultaneously growing wheat landraces and modern wheat varieties. In the model, the variable farm size was shown by the variable representing the proportion of wheat landrace area to total area. This variable was significant at the $99 \%$ confidence level (Table 8). The proportion of wheat landrace area in total area was higher for farms which grew wheat landraces only than for farms growing wheat landraces and modern varieties together. When one considers that the farms, in which the proportion of wheat landrace area to total area is higher than $50 \%$, are smaller farms. It can be said that this variable represents the farm size of the farmers. Farm size has been empirically shown to be positively related to the adoption of modern varieties (Perrin and Winkelmann 1976; Feder et al., 1985; Brush et al., 1992). Larger farmers may benefit from 
economies of scale, be willing to dedicate a smaller proportion of land to experimenting with modern varieties, or may have lower information costs relative to small farmers.

The variable explaining the relationship between the household size and farm size is HHH (The amount of land per household member) (Table 8). The value of $\mathrm{HHH}$ gives an idea of both the wealth status of the farms in terms of income and the amount of manageable land. With a larger value of $\mathrm{HHH}$, the farm generally heads more towards commercial activities. In the model it was found that if the amount of land per household member was high, those farms tended to produce both wheat landraces and improved wheat varieties together.

The other factor examined in the model was the elevation where the wheat landraces were grown. In extremely heterogeneous and highland growing environments, traditional landrace varieties are more likely to be grown than modern varieties since the germplasm developed by centralized breeding programs may not be well adapted to these marginal areas and their microclimates (Jarvis et al., 2000). As a result of the empirical model, elevation, as expected, is an important factor affecting farmers' decisions (Table 8). At higher elevations, generally settlements steer away from the market centers. These locations are generally mountainous and remote areas. In this situation, farmers tend to produce only traditional varieties (wheat landraces).

The other geographical factor is distance to market. A previous study in Turkey by Meng (1997) used market access to empirically explain land-use decisions. Distance to market and road quality both influenced the variety choices of households. Omamo (1998) empirically found that high transport costs directly influenced households and resulted in the decision to plant low-return food crops. Hintze (2002) also empirically tested road quality as an indicator of transaction costs and found it to be positive and significant for modern maize variety adoption. Distance to market, road quality, and access to input and output markets have been shown to affect households' land-use decisions and their production strategies. In our study, distance to market is a significant factor for affecting farmers' decisions of only wheat landrace production or both wheat landrace and modern wheat varieties production (Table 8 ). When we look at the elevation of the farms producing only wheat landraces they are located primarily in mountainous agro-ecological zones. The farmers being far away from marketing places tend to produce only traditional varieties (wheat landraces).

Conclusion: The results provide several implications for in situ conservation of wheat landraces in Turkey. The farmers producing WLR are generally maintaining this farming system in hard geographic conditions. Our results showed that the transition of the farmers from WLR to MWV and socio economic characteristics of the farmers are important factors. The results are shoving that the recovery in the socio economic indications stepping up to abandon WLR of the farmers. Especially the farmers, being younger, having bigger farm size, having better education level and doing agriculture activity in better geographical conditions are in tendency to produce more MWV's in their farms. The inhabitants of Turkish villages are industrious and willing to produce crops which are suitable for the agro-climatic conditions of the region, in order to meet family needs and to sell surplus produce at the local markets. This practice has maintained great diversity in the landraces of many crops. The fact that these varieties, with excellent taste qualities, were created many decades ago in the respective micro-areas with characteristic agro-climatic peculiarities, are grown by an aging population makes our activity in collection and preservation of this wealth priceless, because the desire to cultivate landrace diversity is not being sustained by younger generations.

To maintain genetic diversity in terms of WLR, not only must we know the farmers' socio-economic condition but we also should create or implement new policies for these areas. While policy makers are establishing policy in rural areas, they should establish different policies for specific areas, as well as general policies. The EU Agriculture Development Policy for people living in mountainous regions is a good example. Mountainous rural areas face particular challenges and have specific needs in respect to other rural areas. In the current EU agricultural policy context they are included in the designation of "Less Favored Areas (LFAs)" because they are generally characterized by a short growing season (because of a high altitude), or by steep slopes at a lower altitude, or a combination of the two. Such conditions pose challenges for agriculture and the rural economy in these areas. Specific support instruments have been developed by the EU which are targeted at mountain rural areas, and these include rural development policy measures. If the wheat landraces are grown in such areas, constituting such a policy in Turkey will help the conservation of genetic resources (CGR) and also biodiversity.

Acknowledgement: We would like to thank and extend our best regards to the following people for their invaluable help throughout the research: Dr. Enver KENDAL, Dr. Hakan HEKİMHAN, Dr. Mustafa GÜLLÜ, Ass. Prof. Köksal KARATAŞ, Dr. Emin DÖNMEZ, Sevinç KARABAK, Rahmi TAŞÇI, Oğuzhan ULUCAN, Soner YÜKSEL, Mustafa ÇAKMAK, Dr. Ümran KÜÇÜKÖZDEMİ, Enes YAKIŞIR, İbrahim KAÇMAZ, Ercan DOĞAN, Erdal KABLAN, Adem ESKİĊ, Fatih SARI, Prof. Dr. Ela ATIŞ, Mert ALTINTAŞ, Muhittin BÖGET, Süleyman BAKIRCI, Murat KAN, Dr. Arzu KAN, Ass. Prof. Sezen KÜÇÜKÇONGAR, and all the participating farmers in the study area 


\section{REFERENCES}

Agresti, A. 1996. An Introduction to Categorical Data Analysis. John Wiley and Sons, Inc.

Bardsley, D.K. and I. Thomas. 2005. Valuing local wheat landraces for agrobiodiversity conservation in Northeast Turkey. Agric. Ecosys. and Env. 106: 407-412.

Bayazit, M. and B. Oguz. 1998. Probability and Statistics for Engineers. Birsen Yayinevi, Istanbul.

Bellon, M.R. 1996. The dynamics of crop infraspecific diversity: A conceptual framework at the farmer level. Econ. Botany. 50: 26-39.

Benin, S., M. Smale, J. Pender, B. Gebremedhin and S. Ehui. 2004. The economic determinants of cereal crop diversity on farms in the Ethiopian highlands. Agric. Econ. 31: 197-208.

Bennett, S.J., N. Maxted and C.O. Sabanci. 1998. The ecogeography and collection of grain, forage and pasture legumes in south-west Turkey. Genet. Resour. Crop Evol. 45: 253-262.

Brush, S.B., J.E. Taylor and M.R. Bellon. 1992. Technology adoption and biological diversity in Andean potato agriculture. J. Dev. Econ. 39: 365-387.

Brush, S.B. 1995. In situ conservation of landraces in centers of crop diversity. Crop Sci. 35: 346-354.

Brush, S. and E. Meng. 1998. Farmers' valuation and conservation of crop genetic resources. Genet. Resour. Crop Evol. 45: 139-150.

Buyukozturk, S. 2010. Sosyal Bilimler Için Veri Analizi El Kitabi. Ankara: PegemA Yayinlari.

Davis, P.M. 1985. Flora of Turkey and the East Aegean Islands. Edinburgh University Press, Edinburgh, UK.

Dincer, B., M. Ozaslan and T. Kavasoglu. 2003. Illerin ve bolgelerin sosyo-ekonomik gelişmişlik siralamasi araştirmasi. Kalkinma Bakanlıgı, Bolgesel Gelişme ve Yapisal Uyum Genel Mudurlugu, Mayis, 2003. Ankara, Turkey. Avaialable online at http://bssupgrade. oceaninfo.ru/library/files/39490.pdf

Ergün, M. 1995. Bilimsel Araştirmalarda Bilgisayarla İstatistik Uygulamalari. SPSS for Windows. Ankara: Ocak Yayinlari.

Erkuş, A. 1979. Ankara Ili Yenimahalle İlçesinde Kontrollü Kredi Uygulamasi Yapilan Tarim İşletmelerin Planlanmasi Üzerine Bir Araştirma, Ankara Üniversitesi Ziraat Fakültesi Yayinlari No. 709, Ankara.

Evenson, R.E. and D. Gollin. 1994. Genetic resources, international organizations and rice varietal improvement. Center Discussion Paper No. 713. Economic Growth Center, Yale University, New Haven, $\mathrm{CN}$.

Feder, G., R.E. Just and D. Zilberman. 1985. Adoption of agricultural innovations in developing countries: a survey. Econ. Dev. and Cult. Chan. 33: 255-298.
Gauchan, D., M. Smale, N. Maxted, M. Cole, B. Sthapit, D. Jarvis and M.P. Upadhyay. 2005. Socioeconomic and agroecological determinants of conserving diversity onfarm: the case of rice genetic resources in Nepal. Nepal Agric. Res. J. 6: 89-98.

Gokgol, M. 1939. Türkiye Buğdaylari (Turkish Wheat). Istanbul, Turkey.

Grene, W.H. 2000. Econometric Analysis, $4^{\text {th }}$ Ed. Prentice Hall, NJ USA.

Harlan, J.R. 1995. The Living Fields: Our agricultural heritage. Cambridge: Cambridge University Press.

Hintze, L.H. 2002. Characteristics, transaction costs and adoption of modern varieties in Honduras. Ph.D. Dissertation, North Carolina State University, Raleigh, NC USA.

Iltis, H.H. 1982. Discovery of No. 832: An essay in defense of the National Science Foundation. Desert Plants 3: 175-192.

Jarvis, D.I., L. Myer, H. Klemick, L. Guarino, M. Smale, A.H.D. Brown, M. Sadiki, B. Sthapit and T. Hodgkin. 2000. A training guide for in situ conservation on-farm. Version 1. International Plant Genetic Resources Institute, Rome, Italy.

Kaya, Z., E. Kün and A. Güner. 1997. National Plan for In situ Conservation of Plant Genetic Diversity in Turkey. Milli Egitim Basimevi, Istanbul, Turkey.

Kan, M. 2012. Usage of geographical indication in local economical development and its impact: A case study on Aksehir Cherry. Ph.D. Thesis, Ankara University, Graduate School of Natural and Applied Sciences, Department of Agricultural Economics, Ankara, Turkey.

Kesici, T. and Z. Kocabaş. 2007. Biyoistatistik. Ankara Üniversitesi Eczacilik Fakültesi Biyoistatistik Yayin No: 94, Ankara, Turkey.

Khan, J., S. Khan, M. Islam, S. Ahmad, A. Amanullah, A. Hanan, M.A. Khan and S. Shiekh. 2012. A new barley variety Rakhshan-10 (Az-96) for Balochistan. Pak. J. Agri. Sci. 49: 135-139.

Kurizch, T. 2006. Why do households cultivate landraces? Wheat variety selection and in situ conservation in Turkey. MSc. Thesis, Montana State University, Bozeman, Montana.

Kruzich, T.J. and E. Meng. 2006. Wheat landrace cultivation in Turkey: Household land-use determinants and implications for on-farm conservation of crop genetic resources. International Association of Agricultural Economists Conference, August 12-16, 2006, Gold Coast, Australia.

Maddala, G.S. 1983. Limited-Dependent and Qualitative Variables in Econometrics. Cambridge University Press, Cambridge, UK.

Mazid, A, K.N. Amegbeto, M. Keser, A. Morgounov, K. Peker, A. Bağci, M. Akin, M. Küçükçongar, M. Kan, S. Karabak, A. Semerci, A. Altikat and S. Yaktubay. 2009. 
Adoption and Impacts of Improved Winter and Spring Varieties in Turkey. ICARDA, Aleppo, Syria.

Meng, E. 1997. Land allocation decisions and in-situ conservations of crop genetic diversity resources. The case of wheat land races in Turkey. PhD Thesis, Department of Agricultural and Resource Economics, University of California, Davis, USA.

MoD (Ministry of Development) 2004. İlçelerin sosyoekonomik gelişmişlik siralamasi araştirmasi (2004). Avaialable online at http://kirklareli.gov.tr/90planlama/90diger/dokuman/dpt _ilcelerin_sosyo_ekonomik_gelismislik_siralamasi_aras tirmasi_2004.pdf

Nagarajan, L., M. Smale and P. Glewwe. 2007. Determinants of millet diversity at the household-farm and villagecommunity levels in the dry lands of India: the role of local seed systems. Agric. Econ. 36: 157-167.

National Research Council. 1993. Managing Global Genetic Resources: Agricultural Crop Issues and Policies. National Academy Press, Washington, D.C.

Negassa, A., J. Hellin and B. Shiferaw. 2012. Determinants of adoption and spatial diversity of wheat varieties on household farms in Turkey. International Maize and Wheat Improvement Center (CIMMYT), SocioEconomic Working Paper 2. CIMMYT, Mexico, DF, Mexico.

Nesbitt, M. and D. Samuel. 1996. From stable crop to extinction? The archaeology and history of the hulled wheat's. In: S. Padulosi, K. Hammer and J. Heller (eds.), Hulled wheat's. International Plant Genetic Resources Institute, Rome; pp.41-100.

Newton, A.C., T. Akar, J.P. Baresel, P.J. Bebeli, E. Bettencourt, K.V. Bladenopoulos, J.H. Czembor, D.A. Fasoula, A. Katsiotis, K. Koutis, M. Koutsika-Sotiriou, G. Kovacs, H. Larsson, M.A.A. Pinheiro de Carvalho, D. Rubiales, J. Russell, T.M.M. Dos Santos and M.C. Vaz Patto. 2010. Cereal landraces for sustainable agriculture: A review. Agron. Sustain. Dev. 30: 237-269.

Omamo, S.W. 1998. Transport costs and smallholder cropping choices: An application to Slaya District, Kenya. Amer. J. Agric. Econ. 80:116-123.

Perrin, R. and D. Winkelmann. 1976. Impediments to technological progress on small versus large farms. Amer. J. Agric. Econ. 58: 888-894.

Ral, D. 1968. Sampling Theory. McGraw Hill, New York.

Smale, M., E. Meng, J.P. Brennan and R. Hu. 2003. Determinants of spatial diversity in modern wheat:
Examples from Australia and China. Agric. Econ. 28: 1326.

Sperling, L., M.E. Loevinsohn and B. Ntabomvura. 1993. Rethinking the farmer's role in plant breeding: Local bean experts and on station selection in Rwanda. Exp. Agric. 29: 509-519.

Sahin, K. and I.H. Yilmaz. 2008. Van ili Gürpinar ilçesinde yem bitkileri üretimi ve sorunlari üzerine bir araştirma. Tarim Bilimleri Dergisi, sayi. 14: 16-21.

Tan, A. 1998. Current status of plant genetic resources conservation in Turkey. In: N. Zencirci, Z. Kaya, Y. Anikster, and W.T. Adams (eds.), Proceedings of the International Symposium on In situ Conservation of Plant Genetic Diversity, CRIFC, Ankara, pp.5-16.

Tanno, K. and G. Willcox. 2006. The origins of cultivation of Cicer arietinum L. and Vicia faba L.: early finds from North West Syria (Tell el-Kerkh, late $10^{\text {th }}$ millennium BP). Veg Hist Archaeobot. 15: 197-204.

TSI (Turkish Statistical Institute). 2013. Family Statistics in Turkey, 2012. Available online at http://www.tuik.gov.tr/PreHaberBultenleri.do?id=13662

TSI (Turkish Statistical Institute). 2015. Production Statistics in Turkey, 2015. Available online at http://www.tuik.gov.tr/PreIstatistikTablo.do?istab_id=5 5.

Van Dusen, M.E. 2000. In situ conservation of crop genetic resources in the Mexican Milpa system, B.A. Ph.D. Dissertation in Agricultural and Resource Economics, University of California, Davis, CA USA.

World Bank. 1993. Republic of Turkey: In-situ conservation of genetic diversity. Report No. 11295-TU, Global Environment Coordination Division, World Bank, Washington.

World Bank. 1999. Republic of Turkey: In-situ conservation of genetic diversity. Report No. 11295-TU, Global Environment Coordination Division, World Bank, Washington.

Yavuz, M. 2010. Wheat Flour from Turkey. Export Promotion Center of Turkey. Available online at http://www.economy.gov.tr/upload/sectoralreports/Whe at\%20Flour.pdf

Zencirci, N. and M. Birsin. 2004. From Wheat in Turkey to Bread of World. Paper presented in Agronomy and Crop Science Society Meeting.

Zimmerer, K.S. 1996. Changing fortunes: Biodiversity and peasant livelihood in the Andes. University of California Press, Berkeley. 